\title{
Atmospheric Rivers over the Bay of Bengal Lead to Northern Indian Extreme
}

\section{Rainfall}

Yan Yang ${ }^{1}$, Tongtiegang Zhao ${ }^{3}$, Guangheng $\mathrm{Ni}^{1}$, Ting $\mathrm{Sun}^{1,2^{*}}$

1) State Key Laboratory of Hydro-Science and Engineering, Department of Hydraulic Engineering, Tsinghua University, Beijing 100084, China

2) Department of Meteorology, University of Reading, Reading, RG6 6BB, $U K$

3) Commonwealth Scientific and Industrial Research Organization, Division of Land and Water, Melbourne 3168, Australia

* Corresponding Author: sunting@tsinghua.edu.cn

This is the author manuscript accepted for publication and has undergone full peer review but has not been through the copyediting, typesetting, pagination and proofreading process, which may lead to differences between this version and the Version of Record. Please cite this article as doi: $10.1002 /$ joc.5229

This article is protected by copyright. All rights reserved. 


\section{Abstract}

Atmospheric rivers (ARs), filamentary patterns of strong water vapor fluxes, play a prominent role in global poleward moisture transport and have profound impacts on extreme rainfalls (ERs). Previous AR research has mainly focused on the mid-latitude regions, whereas the characteristics of ARs in low latitudes and their relationship with local ERs remain largely unknown. This study investigates the spatiotemporal characteristics of ARs over the Bay of Bengal and their relationship with ERs after landing on the northern Indian subcontinent using the ERA-Interim reanalysis data. During the study period from 1979 to 2011, a total of 149 ARs have been identified, which feature a bimodal temporal pattern with more events observed in May and October. The AR axes generally stretch northeastwards over the bay and land in Bangladesh and Burma. 24\% of ARs occurring during tropical cyclones implies a possible connection between them, in addition to the similar intra-annual distribution. In summer, as the tropical cyclones are weak and the northward water vapor flux decreases due to topographic blocking of the Western Ghats, it is less likely to form intensified water vapor pathway, though the atmospheric humidity is high in the study region. Furthermore, a close correlation between ARs and ERs is manifested. A large proportion of ARs would lead to ERs, with a small fraction of ERs occur after ARs. In addition, although persistent ARs constitute the majority of identified events, rainfall intensity 
will not be enhanced by the increase in AR duration. This study enriches the knowledge of AR characteristics in low latitudes and provides new pathways to understand the hydrological cycles in the Indian Peninsula and the Bay of Bengal.

\section{Keywords:}

Atmospheric river; Bay of Bengal; Tropical cyclone; Extreme rainfall; ERA-Interim dataset 


\section{Introduction}

Atmospheric rivers (ARs), featured by long, narrow corridors of enhanced water vapor transport, are responsible for more than $90 \%$ of the horizontal water vapor transport from tropics or subtropics into higher latitudes, and facilitate the precipitation that is crucial to water supply (Zhu and Newell 1998; Ralph et al. 2011a; Bao et al. 2006). Some strong ARs that contain large amount of water vapor associated with fierce winds may lead to extreme rainfall (ER) and floods (e.g., Ralph et al. 2004; Lavers et al. 2011). Consequently, ARs are widely recognized for the crucial role in the global water cycle (e.g., Zhu and Newell 1998) and particularly those hydrometeorological extremes (Neiman et al. 2008b).

In the mid-latitudes, these intensified water vapor plumes are often manifested as moisture convergence in extratropical cyclone warm sectors and the pre-cold-frontal low-level jet region (Ralph et al. 2004, 2006; Bao et al. 2006; Stohl et al. 2008). Two moisture sources are considered responsible for AR formation: local moisture convergence along the trailing cold fronts and direct poleward transport of tropical moisture (Bao et al. 2006). In addition, Dacre et al. (2015) found that water vapor in the cyclones' warm sector is more responsible for the generation of high water vapor content, compared with long-distance transport of water vapor from subtropics, which 
explains the high frequency of wintertime ARs in mid-latitudes. Furthermore, Zhu and Newell (1998) speculated that tropical ARs may be related to large-scale convergence in boundary regions such as the intertropical convergence zone (ITCZ), rather than baroclinic cyclones.

In the vicinity of ARs, cloud-top temperatures are colder, indicating that deeper clouds (mid- and high clouds) are associated with deep convective systems that promote heavy precipitation by strong upward motion up to the tropopause with a large amount of cloud liquid (Ralph et al. 2004, 2011b). Most of the water vapor in ARs is transported within the lowest $2.5 \mathrm{~km}$ of the atmosphere with moist-neutral stratification (Ralph et al. 2005). The combination of lower-troposphere moist neutrality and strong horizontal winds creates an ideal avenue for strong orographic precipitation when ARs approach high terrains (Ralph et al. 2011a; Lavers et al. 2011, 2012; Viale and Nunez 2010). For example, ARs stretching from the eastern Pacific Ocean to western North America are regarded as a primary meteorological contributor in flood generation and water resources in California as ARs bring in $20-50 \%$ of the total precipitation in the long term (Dettinger et al. 2011). Additionally, landfalling AR is found to be a strong precursor to the ER in the western European seaboard: 8 of the 10 largest ER events were preceded by ARs (Lavers and Villarini 2013b). The concept of ARs provides a new 
and objective framework to examine and quantify atmospheric conditions related to ERs (Ralph et al. 2006).

Previous techniques for AR identification are primarily based on the intensity and spatial features of atmospheric water vapor (Gimeno et al. 2014). The intensity is usually quantified by the vertically integrated water vapor (IWV) and vertically integrated horizontal water vapor transport (IVT). IWV can either be retrieved from the Special Sensor Microwave Imager (SSM/I) (Ralph et al. 2004), or calculated using atmospheric reanalysis data; while IVT can be determined by using atmospheric reanalysis data (Zhu and Newell 1998). Compared with IWV, IVT is more desirable for AR detection due to its closer relationship with orographic precipitation (Neiman et al. 2002; Guan and Waliser 2015). In terms of geometric features, length, width and length/width ratio are usually used in AR identification (Guan and Waliser 2015). However, thresholds of these measures are not universal but determined region by region (Gimeno et al. 2014). For instance, Neiman et al. (2008a) suggested that narrow plumes of SSM/I with IWV values $>20 \mathrm{~mm}$ (i.e., $>2000 \mathrm{~km}$ long and $<1000 \mathrm{~km}$ wide) can be identified as ARs along the west coast of North America, whereas ARs at the Midwestern USA are found to have higher IWV intensity (in the range of 30-55 $\mathrm{mm}$ ) and longer extension (about $3000 \mathrm{~km}$ ) (Moore et al. 2012). 
Although ARs in mid-latitudes are well studied by previous research, characteristics of ARs in lower latitudes are remaining largely unknown. Meanwhile, the Bay of Bengal is under strong influence of Indian monsoon, South Asian monsoon and notable tropical cyclones and thus becomes vulnerable to devastating rainfall and floods that can be induced by ARs. Additionally, inland penetration of ARs in concomitant with the Himalayas may facilitate the topographic ERs in this region. As such, we focus on ARs over the Bay of Bengal and examine their relationship with ERs over the Indian subcontinent (Figure 1).

The objectives of the study are (1) to investigate the spatiotemporal characteristics of ARs over the Bay of Bengal, and (2) to examine their relationship with ERs in the northern Indian subcontinent. In the remainder of this paper, we first introduce an algorithm for AR identification and apply it over the Bay of Bengal. Next, based on the results of identified ARs, we analyze their characteristics and relationship with ERs in the northern Indian subcontinent.

\section{Methodology}

\subsection{Data}


The ERA-Interim dataset (Dee et al. 2011) at a $1.5^{\circ}$ resolution spanning from 1979 to 2011 is used in this study. The ERA-Interim dataset features better representation of hydrological cycle (Berrisford et al. 2011) and has been widely used in identifying moisture origins (Zhao et al. 2015), delineating water vapor transport pathways (Dong et al. 2016), etc. Especially, it can represent key AR characteristics (Guan and Waliser 2015). In the dataset, the specific humidity and the zonal and meridional wind fields are available at a $6 \mathrm{~h}$ resolution, while the precipitation and evaporation are provided at a 3 $\mathrm{h}$ resolution. The specific humidity and horizontal wind fields are used in the AR identification algorithm, while evaporation between $1000 \mathrm{hPa}$ and $175 \mathrm{hPa}$ is used to correct precipitation by taking condensation as a part of precipitation. Also, as the rainfall is available at a relative coarse spatial resolution (i.e., $1.5^{\circ}$ ), some subsynoptic-scale gradients, such as those associated with orographic processes over mountain barriers, may be smoothed out (Rutz et al. 2014). Nevertheless, the ERA-Interim precipitation has the same spatial coverage and consistency between the $\mathrm{AR}$ and ER results that will facilitate the exploration of their correlation in the later sections.

\subsection{ER Identification}

An ER is defined as the $90^{\text {th }}$ percentile of the maximum daily rainfall over the study 
area during 1979-2011 (Champion et al. 2015). In addition, only rainy days with daily precipitation larger than $1 \mathrm{~mm}$ are included (Eiras-Barca et al. 2016). The $90^{\text {th }}$ percentile threshold is calculated separately for each month (Figure 2).

\subsection{AR Identification}

We modify the method in Lavers and Villarini (2013a) for central United States in two aspects: (1) Two reference latitudes are used in this study: $24^{\circ} \mathrm{N}$ and $27^{\circ} \mathrm{N}$ that represent the coastal and interior areas respectively, in consideration of the variation of IVT strength along latitude; (2) Equivalent width and direction thresholds are used in the back trajectory algorithm in order to filter out invalid identification results.

The detection method is based on the IVT field derived from specific humidity and wind fields between 1000 and $300 \mathrm{hPa}$ given by

$$
\mathrm{IVT}=\sqrt{\left(\frac{1}{g} \int_{1000}^{300} q u d p\right)^{2}+\left(\frac{1}{g} \int_{1000}^{300} q v d p\right)^{2}}
$$

where $q$ is the specific humidity in $\mathrm{kg} \mathrm{kg}^{-1}, u$ and $v$ are the zonal wind and meridional wind in $\mathrm{m} \mathrm{s}^{-1}$, respectively, $g$ is the acceleration of gravity in $\mathrm{m} \mathrm{s}^{-1}$ (Neiman et al. 2008a; Lavers and Villarini 2013a, 2013b). 
Monthly IVT strength thresholds are applied in the AR identification considering the notable intra-annual variability of IVT intensity (Champion et al. 2015) and ER occurrence. The IVT threshold is determined as follows. The maximum values of IVT at reference latitudes (i.e., $24^{\circ} \mathrm{N}$ and $27^{\circ} \mathrm{N}$ ) at $1200 \mathrm{UTC}$ of each day are first regrouped by month, then the $85^{\text {th }}$ percentiles of each group are determined as the monthly thresholds. We note that IVT results smaller than $250 \mathrm{~kg} \mathrm{~m}^{-1} \mathrm{~s}^{-1}$ are excluded as they are too small in winter (Rutz et al. 2014).

Besides the IVT strength threshold determination, the two reference latitudes are also used in locating the ending point of AR axis (i.e., the central line of an AR). By identifying ARs based on the three latitudes of the study area (i.e., $24^{\circ} \mathrm{N}, 25.5^{\circ} \mathrm{N}$ and $27^{\circ} \mathrm{N}$ ), we found the results based on $24^{\circ} \mathrm{N}$ and $27^{\circ} \mathrm{N}$ are sufficient to cover all AR events. Thus, we employ $24^{\circ} \mathrm{N}$ and $27^{\circ} \mathrm{N}$ as reference latitudes (Full details of reference latitude selection refer to Appendix).

The next step of AR identification is to determine the AR axis, which in combination with geometry thresholds will be used to filter out the objects with less physical meanings: as ARs refer to the strong poleward water vapor transport, objects not satisfying such directionality need to be excluded. To start with, we define the ending 
point of AR axis as the location of the maximum IVT at reference latitudes. Then a back trajectory algorithm is used in the axis identification (Figure 3): we search for the highest IVT by comparing the adjacent grid cells to the south, southeast and southwest, which are selected because of the poleward transport feature, and such procedure is iterated until a total of 14 successive grid points are obtained to form an axis. If 14 grids are taken south of reference latitude, the identified axis would be more than $2000 \mathrm{~km}$ long (Ralph et al. 2004).

Direction and width thresholds are then applied to distinguish ARs from monsoon and tropical cyclones. Moisture convergence in a low-pressure center and intense surface wind of summer monsoon are likely to be mistakenly identified as ARs if only IVT strength and length are considered. The direction of an AR should satisfy the condition that the included angle between mean transport direction and the line connecting two endpoints of the axis is not greater than $45^{\circ}$. The mean transport direction is the mean moisture transport direction of grids along the axis. Here we use the equivalent width (EW) to represent the width of an AR, which should be less than $1000 \mathrm{~km}$ (7 grids) (Ralph et al. 2004; Neiman et al. 2008a). The EW is calculated as:

$$
E W=\frac{\text { area }}{\text { length }}
$$

where length is the number of the contiguous grids (14 in this case), area is the total 
number of grids with IVT strength greater than the monthly threshold in the axis coverage region, which is a sub-domain of the rectangular region extending diagonally from $\left(76.5^{\circ} \mathrm{E}, 0^{\circ} \mathrm{N}\right)$ to $\left(99^{\circ} \mathrm{E}, 30^{\circ} \mathrm{N}\right)$ : if the axis stretches zonally (meridionally), its endpoints will determine the north-south (west-east) boundary of the coverage region.

To briefly summarize, AR identification includes three steps: (1) obtaining the original AR occurrence time based on the IVT strength threshold; (2) conducting AR axis identification and (3) filtering out the mistakenly identified AR structures with width and direction thresholds. Figure 4 illustrates the brief workflow of AR identification algorithm.

\section{Results and discussion}

\subsection{IVT intensity}

Apparent seasonality in the atmospheric water vapor indicated by IVT is observed in the study region (Figure 5). This pattern features high precipitation due to the strong influence of southwesterly monsoon with abundant water vapor (Zhao et al. 2015). In general, high IVT (e $250 \mathrm{~kg} \mathrm{~m}^{-1} \mathrm{~s}^{-1}$ ) is observed in summer (JJA, Figure 5b) and autumn (SON, Figure 5c) but winter (DJF, Figure 5d) and spring (MAM, Figure 5a). Annual IVT exhibits a single-peak trend with the maximum in July as high as $600 \mathrm{~kg} \mathrm{~m}^{-1} \mathrm{~s}^{-1}$. In 
May (not shown) and autumn (SON, Figure 5c), the water vapor belt forms over the bay and extends meridionally to the northeast of the study region. While in JJAS (Figure 5e), the seasonal movement of the ITCZ, manifesting as monsoon, prompts the seasonal rainfall variations. High rainfalls occur over the monsoon zone around $20^{\circ} \mathrm{N}$ stretching northwestward from the head of the Bay of Bengal. And most of the summertime monsoon rainfalls occur in association with the propagation of synoptic-scale convective systems from the Bay of Bengal along the monsoon zone (Gadgil 2003; Schneider et al. 2014). Also, as the East Asian monsoon becomes stronger in autumn, water vapor brought by the southwesterly and East Asian monsoon converges near the Longitudinal Range-Gorge Region in China (yellow box in Figure 5c). While the wintertime IVT is relatively too small to impose apparent influence on the precipitation.

Inland penetration of ARs implies their possible impacts on areas that are distant from the landfalling locations (Guan and Waliser 2015; Rutz et al. 2014). Considering the high possibility of AR penetration, it is necessary to examine the possible extents of ARs in the study region. As such, the dependence of IVT intensity on latitude is assessed using their monthly thresholds of each latitude (Figure 6). A slight increase in IVT is observed from $24^{\circ} \mathrm{N}$ to $25.5^{\circ} \mathrm{N}$, which can be attributed to the high local evaporation from densely covered rivers in this area. Although IVT then decreases from 
$25.5^{\circ} \mathrm{N}$ to $27^{\circ} \mathrm{N}$, the southern foot of the Himalayas, its relatively high value (larger than $250 \mathrm{~kg} \mathrm{~m}^{-1} \mathrm{~s}^{-1}$ ) implies ARs may penetrate into the interior area of the study region.

\subsection{AR}

The intra-annual distribution of AR demonstrates a clear dual-peak pattern (peaking in May and October) (Figure 6), which differs from single-peak pattern of ARs (peaking in winter) observed in mid-latitudes. It is also noteworthy that the intra-annual variation in AR does not follow that in IVT (single-peak pattern in summer), implying the summertime decrease in AR events is caused not by the reduced IVT intensity but possibly by the seasonal movement of water vapor belts: as the belt encounters the Western Ghats (cf. Section 3.1), the high deficit in water vapor hampers the formation of AR in summer.

To investigate the spatial pattern of ARs, AR axis is introduced as the indicator. Comparable spatial occurrence patterns of ARs are observed in spring (Figure 7a) and autumn (Figure 7c) with inland occurrence in Burma, Bangladesh and India. While less occurrence of ARs is observed in summer, the intensity of AR is much stronger than those in other seasons with deeper penetration (Figure $7 \mathrm{~b}$ ). The occurrence of AR is significantly less in winter (Figure 7d). Figure 8a-8d show examples of ARs identified 
in the four seasons.

Considering the similar bimodal temporal distribution of ARs and tropical cyclones over the Bay of Bengal (Li et al. 2012), we hypothesize that possible correlation may exist between them. Using the tropical cyclone best-track data from the Joint Typhoon Warning Center (JTWC), we compare the occurrence of ARs and tropical cyclones. The results indicate that $24 \%$ of ARs occurred during tropical cyclones with most in the end of the best track periods. We note that this percentage could be larger because ARs that occurred after the tropical cyclones were excluded. Compared with the findings in southeastern United States that only $\sim 7 \%$ of ARs occurred during tropical and subtropical cyclones (Debbage et al. 2017), it is indicated that ARs in the Bay of Bengal are heavily influenced by tropical activity. Figure 8c shows the spatial pattern of a typical AR that occurred during the active tropical cyclone period, indicating the role of tropical cyclones in facilitating the longitudinal transport of water vapor that feeds ARs.

Based on the hypothesis, the low summertime occurrence of ARs may also be attributed to other factors (e.g., vertical wind shear and vorticity (Li et al. 2012)) that limit the formation of tropical cyclones, in addition to the weakened water vapor transport due to topographic blocking (cf. Section 3.1). Also, water vapor belts are sometimes led by the 
local convective systems to the East India during the summer monsoon (Figure 8e).

\subsection{Relevance to Extreme Precipitation}

The relevance of ARs to ERs is investigated by testing the following hypotheses: 1) ERs occur after ARs and 2) ARs lead to ERs. During the period from 1979 to 2011, a total of 1190 ERs have been identified with the spatial distribution concentrating mainly along the south foot of the Himalayas (Figure 9), suggesting the importance of orographic effect in the formation of ERs. Furthermore, we term those ERs that occur after ARs no later than 24 hours and appear in the vicinity of the AR axis (i.e. within 1.5 degree from the AR axis) as AR-related ERs (AERs) hereinafter. The above hypotheses are then tested through two ratios: 1) $r_{\mathrm{ER}}$ (the occurrences of AERs over all ERs) and 2) $r_{\mathrm{AR}}$ (the occurrences of AERs over all ARs). $r_{\mathrm{ER}}$ indicates the fraction of ERs that are associated with ARs, whereas $r_{\mathrm{AR}}$ suggests the fraction of ARs that lead to ERs.

Noticeable seasonality is found in $r_{\mathrm{ER}}$ (Figure 10a) with higher values of $\sim 14 \%$ observed in October and November (the post-monsoon season) while the lowest values in summer and winter. Such seasonality could be explained by the variability of synoptic forcing and large-scale moisture availability (Eiras-Barca et al. 2016). During the transitional monsoon season, AERs are favored by the abundant moisture conveyed 
by ARs that satisfies the dynamic conditions for ERs. However, in the warm season, precipitation tends to be more associated with convective systems (Lavers and Villarini 2013b; Champion et al. 2015; Eiras-Barca et al. 2016; Gadgil, 2003). Hence, the moisture availability is no longer a restriction due to local moist convection favored by higher temperatures. Meanwhile the tropical cyclones are less frequent, so ERs are mostly attributable to local convective systems rather than ARs (Champion et al. 2015).

Apparent seasonality is found in $r_{\mathrm{AR}}$ as well (Figure 10b): wintertime values are much higher than those in other seasons. Compared with $r_{\mathrm{ER}}, r_{\mathrm{AR}}$ shows larger magnitude over the whole year, indicating stronger correlation of AER with AR than with ER. In particular, during the dry boreal winter, the high $r_{\mathrm{AR}}$ (i.e., $>50 \%$ ) highlights the crucial role of ARs in forming ERs by supplying abundant moisture. As for the spatial distribution of ERs, local topographic lift is found of great importance in facilitating AERs. Therefore, higher winter half-year $r_{\mathrm{AR}}$ also indicates the potential of ARs in inland penetration. On the other hand, the relatively low $r_{\mathrm{AR}}$ in spring could be attributed to ARs that are not strong enough to penetrate deeply inland.

Based on the results of $r_{\mathrm{ER}}$ and $r_{\mathrm{AR}}$, we thus infer that only a very small fraction of ERs occur after ARs whereas a high portion of ARs can lead to ERs in the study region. 
Furthermore, as the positive relationship is found between the duration of AR and the rainfall/streamflow during AER (i.e. longer AR duration potentially induce higher rainfall/streamflow, see Lavers and Villarini 2013a in central United States, Ralph et al. 2006 in northern California), we also examine such relationship in the study region.

ARs are categorized into three groups according to their durations: 1) AR-all: all AR events are included; 2) AR-12h: AR events longer than 12 hours are included; 3) AR-18h: AR events longer than 18 hours are included. Results show that $70 \%$ of the 149 AR events last more than 12 hours, and up to 50\% ARs fall into group AR-18h. It is noteworthy that similar $r_{\mathrm{AR}}$ values of $\sim 50 \%$ are found across the three groups (Figure 11), suggesting the AR duration has minimal influence on the intensity of ERs.

\section{Concluding remarks}

In this study, we investigate the spatiotemporal characteristics of ARs over the Bay of Bengal and their correlation with ERs in study area. In total, 149 ARs are identified from 1979 to 2011 using a modified algorithm of AR identification in the IVT field, over $50 \%$ of which last more than 18 hours. The modification includes width and direction thresholds, in addition to length and IVT strength criteria, to filter out the monsoon and tropical cyclones, which could be mistakenly identified as ARs in the 
tropics. The choice of reference latitude is shown to be crucial in AR identification, given the remarkable variation of IVT threshold along latitude. Two reference latitudes are found to be sufficient to capture all AR events of the study region.

The intra-annual variation of AR occurrence shows a bimodal feature (i.e., peaking in May and October) that is consistent with the temporal distribution of tropical cyclones over the Bay of Bengal. These moisture corridors form over the bay, extend northeastwards, and penetrate inland into Burma, Bangladesh and India. The spatiotemporal characteristics of ARs demonstrate that the southwesterly moisture transport brings abundant water vapor from the tropics to the northern continent and indicate that tropical cyclones may enhance this poleward moisture transport. Moreover, the high occurrence frequency of ARs in May is different with tropical cyclones but similar with supercyclones ( $\mathrm{Li}$ et al. 2012), implying that the intensity of tropical cyclones might influence the occurrence of ARs. The low frequency of ARs in summer could be explained by the lack of cyclones and the weak northward water vapor transport due to topographic blocking.

Furthermore, a high correlation between ARs and ERs is verified. Although the fraction of ERs occurring after ARs is relatively small, a large proportion of ARs lead to ERs. In 
particular, the moisture conveyed by ARs plays an important role in forming ERs during the dry boreal winter. Besides, local convective systems responsible for most summer ERs explain the low occurrence of ERs induced by ARs in summer. On the other hand, the fraction of ARs leading to ERs indicates the potential of ARs in facilitating the landing of ERs considering the crucial role of mountains in the ER formation. In addition, the duration of ARs has minimal influence on the intensity of ERs.

This study for the first time investigates the spatiotemporal characteristics of ARs in low latitudes and their relationship with ERs. Although both are closely correlated with ERs, the dual-peak pattern in occurrence and strong inland penetration of ARs in low latitudes highlight their distinct features from ARs in mid-latitude. These may help better understand the weather extremes and hydrological cycles in this region. One of the limitations that need to appreciate is the use of a single reanalysis dataset: analysis based on more datasets can help generalize the findings of this study. Additionally, the mechanism behind which tropical activities govern ARs needs further exploration. 


\section{Acknowledgement}

The study is supported by NSFC under 51679119 and 91647107 , and by China Postdoctoral Science Foundation under grant 2015T80093. The ERA-Interim dataset used in this study is provided by ECMWF. The authors thank the three anonymous reviewers for their constructive and insightful comments that significantly improve the quality of this work. 


\section{Appendix: ARs identified based on two reference latitudes}

In this work, we apply two reference latitudes in AR identification and obtain two different groups of ARs. The two reference latitudes are capable to envelope the variation of grid IVT strength over the continent where ARs land (Figure A1). Furthermore, compared with the global AR dataset of Guan and Waliser (2015), although the total number of identified ARs in our work (the oceanic area of a rectangular region extending diagonally from $\left(76.5^{\circ} \mathrm{E}, 0^{\circ} \mathrm{N}\right)$ to $\left.\left(99^{\circ} \mathrm{E}, 24^{\circ} \mathrm{N}\right)\right)$ during 1979-2011 is relatively smaller, more than half of our results overlap with the global dataset. Both results show the high frequency of ARs in warm season and a reduction in July (Figure A2). The disparity in the amount of ARs identified can be attributed to three reasons: 1) exclusion of eastward and westward tracks in the back trajectory algorithm to focus on the water vapor directly from the Bay rather than from the Arabian Sea and the South China Sea across land; 2) a much higher fixed lower limit (i.e. $250 \mathrm{~kg} \mathrm{~m}^{-1} \mathrm{~s}^{-1}$ ) (Rutz et al. 2014); 3) exclusion of invalid ARs using equivalent width and direction thresholds during monsoon season (JJAS).

In addition, the difference between the $24^{\circ} \mathrm{N}$ and $27^{\circ} \mathrm{N}$ AR groups might be due to three possible causes: 1) transport delay, 2) reduction in IVT threshold and 3) geometry thresholds related uncertainty. Geometry filtering acting on AR axis structures with 
ending points on different reference latitudes is likely to yield different results, even if at the same occurrence time. However, as this impact is difficult to quantify, we do not include the assessment in this section.

To assess the differences caused by transport delay, we choose an average lag of $5 \mathrm{~d}$ through sensitivity analysis, considering the time scale of moisture recycling ranges from $2 \mathrm{~d}$ to $10 \mathrm{~d}$ over the study region and the fast feedback is observed in the summer (van der Ent and Savenije 2011). Only those ARs in $24^{\circ} \mathrm{N}$ and $27^{\circ} \mathrm{N}$ occurring within the average lag (i.e., $5 \mathrm{~d}$ ) are considered to be successive events, by which $24 \%$ of the AR events that identified at $27^{\circ} \mathrm{N}$ can be categorized as successive ones.

Then, we analyze the impact of IVT threshold reduction on the AR identification. Given the lower IVT threshold at $27^{\circ} \mathrm{N}$ compared with $24^{\circ} \mathrm{N}$, we thus apply the threshold at $27^{\circ} \mathrm{N}$ to the dataset of $24^{\circ} \mathrm{N}$ to examine the impact of IVT threshold reduction. Based on the IVT threshold at $27^{\circ} \mathrm{N}, 185$ ARs are identified at $24^{\circ} \mathrm{N}$, of which 26 events overlap with those identified at $27^{\circ} \mathrm{N}$.

The different groups of ARs identified based on the two latitudes have a marginal overlap of 6 events. Besides transport delay and IVT threshold reduction, there are still 
$37 \%$ mismatched events in the AR group based on $27^{\circ} \mathrm{N}$, which could be partly attributed to geometry related filtering.

Moreover, apparent differences are found between the identified AR groups based on different reference latitudes (Figure A3): $24^{\circ} \mathrm{N}, 27^{\circ} \mathrm{N}$ and the complete list (i.e., the AR group consisting results from both $24^{\circ} \mathrm{N}$ and $27^{\circ} \mathrm{N}$ ). Large fluctuations are observed in the inter-annual AR occurrence frequency. For instance, the annual AR occurrence ranges between zero and fourteen in the complete list, with the year 1988 witnessing the most AR events. Also, it is noteworthy that bursts of AR occurrence are observed in the $24^{\circ} \mathrm{N}$ group during each decade, implying the existence of inherent decadal frequency of ARs in this region. On the contrary, the occurrence fluctuation of $27^{\circ} \mathrm{N}$ groups is relatively milder in the study period with slightly growing trend. 


\section{Reference}

Bao JW, Michelson SA, Neiman PJ, Ralph FM, Wilczak JM. 2006. Interpretation of enhanced integrated water vapor bands associated with extratropical cyclones: Their formation and connection to tropical moisture. Monthly Weather Review 134: 1063-1080.

Berrisford P, Dee DP, Poli P, Brugge R, Fielding K, Fuentes M, Kållberg PW, Kobayashi S, Uppala S, Simmons A. 2011. The ERA-Interim archive Version 2.0. ERA Report Series, ECMWF, 23.

Champion AJ, Allan RP, Lavers DA. 2015. Atmospheric rivers do not explain UK summer extreme rainfall. Journal of Geophysical Research: Atmospheres 120: $6731-6741$.

Dacre HF, Clark PA, Martinez-Alvarado O, Stringer MA, Lavers DA. 2015. How do atmospheric rivers form? Bulletin of the American Meteorological Society 96: 1243-1255.

Debbage N, Miller P, Poore S, Morano K, Mote T, Marshall Shepherd J. 2017. A climatology of atmospheric river interactions with the southeastern United States coastline. International Journal of Climatology.

Dettinger MD, Ralph FM, Das T, Neiman PJ, Cayan DR. 2011. Atmospheric rivers, floods and the water resources of California. Water 3. 
Dee DP, Uppala SM, Simmons AJ, Berrisford P, Poli P, Kobayashi S, Andrae U, Balmaseda MA, Balsamo G, Bauer P, Bechtold P, Beljaars ACM, van de Berg L, Bidlot J, Bormann N, Delsol C, Dragani R, Fuentes M, Geer AJ, Haimberger L, Healy SB, Hersbach H, Hólm EV, Isaksen L, Kållberg P, Köhler M, Matricardi M, McNally AP, Monge-Sanz BM, Morcrette JJ, Park BK, Peubey C, de Rosnay P, Tavolato C, Thépaut JN and Vitart F. 2011. The ERA-Interim reanalysis: configuration and performance of the data assimilation system. 2011. Quarterly Journal of the Royal Meteorological Society 137: 553-597.

Dong W et al. 2016. Summer rainfall over the southwestern Tibetan Plateau controlled by deep convection over the Indian subcontinent. Nature Communications 7: 10925.

Eiras-Barca J, Brands S, Miguez-Macho G. 2016. Seasonal variations in North Atlantic atmospheric river activity and associations with anomalous precipitation over the Iberian Atlantic Margin. Journal of Geophysical Research: Atmospheres 121: 931-948.

Gadgil S. 2003. The Indian monsoon and its variability. Annual Review of Earth and Planetary Sciences 31: 429-467.

Gimeno L, Nieto R, Vázquez M, Lavers DA. 2014. Atmospheric rivers: a mini-review. Frontiers in Earth Science 2. 
Guan B, Waliser DE. 2015. Detection of atmospheric rivers: Evaluation and application of an algorithm for global studies. Journal of Geophysical Research: Atmospheres 120: 12514-12535.

Lavers DA, Villarini G. 2013a. Atmospheric rivers and flooding over the Central United States. Journal of Climate 26: 7829-7836.

Lavers DA, Villarini G. 2013b. The nexus between atmospheric rivers and extreme precipitation across Europe. Geophysical Research Letters 40: 3259-3264.

Lavers, D. A., G. Villarini, R. P. Allan, E. F. Wood, and A. J. Wade, 2012: The detection of atmospheric rivers in atmospheric reanalyses and their links to British winter floods and the large-scale climatic circulation. Journal of Geophysical Research: Atmospheres, 117: D20106.

Lavers DA, Allan RP, Wood EF, Villarini G, Brayshaw DJ, Wade AJ. 2011. Winter floods in Britain are connected to atmospheric rivers. Geophysical Research Letters 38: L23803.

Li Z, Yu W, Li T, Murty VSN, Tangang F. 2012. Bimodal character of cyclone climatology in the Bay of Bengal modulated by monsoon seasonal cycle. Journal of Climate 26: 1033-1046.

Moore BJ, Neiman PJ, Ralph FM, Barthold FE. 2012. Physical Processes Associated with Heavy Flooding Rainfall in Nashville, Tennessee, and Vicinity during 1-2 May 
2010: The Role of an Atmospheric River and Mesoscale Convective Systems. Monthly Weather Review 140: 358-378.

Neiman PJ, Ralph FM, White AB, Kingsmill DE, Persson POG. 2002. The statistical relationship between upslope flow and rainfall in California's coastal mountains: Observations during CALJET. Monthly Weather Review 130: 1468-1492.

Neiman PJ, Ralph FM, Wick GA, Lundquist JD, Dettinger MD. 2008a. Meteorological characteristics and overland precipitation impacts of atmospheric rivers affecting the west coast of North America based on eight years of SSM/I satellite observations. Journal of Hydrometeorology 9: 22-47.

Neiman PJ, Ralph FM, Wick GA, Kuo YH, Wee TK, Ma Z, Taylor GH, Dettinger MD. 2008b. Diagnosis of an Intense Atmospheric River Impacting the Pacific Northwest: Storm Summary and Offshore Vertical Structure Observed with COSMIC Satellite Retrievals. Monthly Weather Review 136: 4398-4420.

Ralph FM, Neiman PJ, Wick GA. 2004. Satellite and CALJET aircraft observations of atmospheric rivers over the Eastern North Pacific Ocean during the winter of 1997/98. Monthly Weather Review 132: 1721-1745.

Ralph FM, Neiman PJ, Rotunno R. 2005. Dropsonde observations in low-level jets over the Northeastern Pacific Ocean from CALJET-1998 and PACJET-2001: Mean vertical-profile and atmospheric-river characteristics. Monthly Weather Review 133: 
889-910.

Ralph FM, Neiman PJ, Wick GA, Gutman SI, Dettinger MD, Cayan DR, White AB. 2006. Flooding on California's Russian River: Role of atmospheric rivers. Geophysical Research Letters 33, L13801.

Ralph FM, Dettinger MD. 2011a. Storms, floods, and the science of atmospheric rivers. Eos, Transactions American Geophysical Union 92: 265-266.

Ralph FM, Neiman PJ, Kiladis GN, Weickmann K, Reynolds DW. 2011b. A Multiscale Observational Case Study of a Pacific Atmospheric River Exhibiting Tropical-Extratropical Connections and a Mesoscale Frontal Wave. Monthly Weather Review 139: 1169-1189.

Rutz JJ, Steenburgh WJ, Ralph FM. 2014. Climatological characteristics of atmospheric rivers and their inland penetration over the Western United States. Monthly Weather Review 142: 905-921.

Schneider T, Bischoff T, Haug GH. 2014. Migrations and dynamics of the intertropical convergence zone. Nature 513: 45-53.

Stohl A, Forster C, Sodemann H. 2008. Remote sources of water vapor forming precipitation on the Norwegian west coast at $60^{\circ} \mathrm{N}-\mathrm{a}$ tale of hurricanes and an atmospheric river. Journal of Geophysical Research: Atmospheres 113: D05102.

van der Ent RJ, Savenije HHG. 2011. Length and time scales of atmospheric moisture 
recycling. Atmosphric Chemistry and Physics 11: 1853-1863.

Viale M, Nuñez MN. 2010. Climatology of winter orographic precipitation over the subtropical central Andes and associated synoptic and regional characteristics. Journal of Hydrometeorology 12: 481-507.

Wu S, Pan T, Cao J, He D, Xiao Z. 2012. Barrier-corridor effect of longitudinal range-gorge terrain on monsoons in Southwest China. Geographical Research 1: $1-13$.

Zhao T, Zhao J, Hu H, Ni G. 2015. Source of atmospheric moisture and precipitation over China's major river basins. Frontiers of Earth Science 10: 159-170.

Zhu Y, Newell RE. 1998. A proposed algorithm for moisture fluxes from atmospheric rivers. Monthly Weather Review 126: 725-735. 


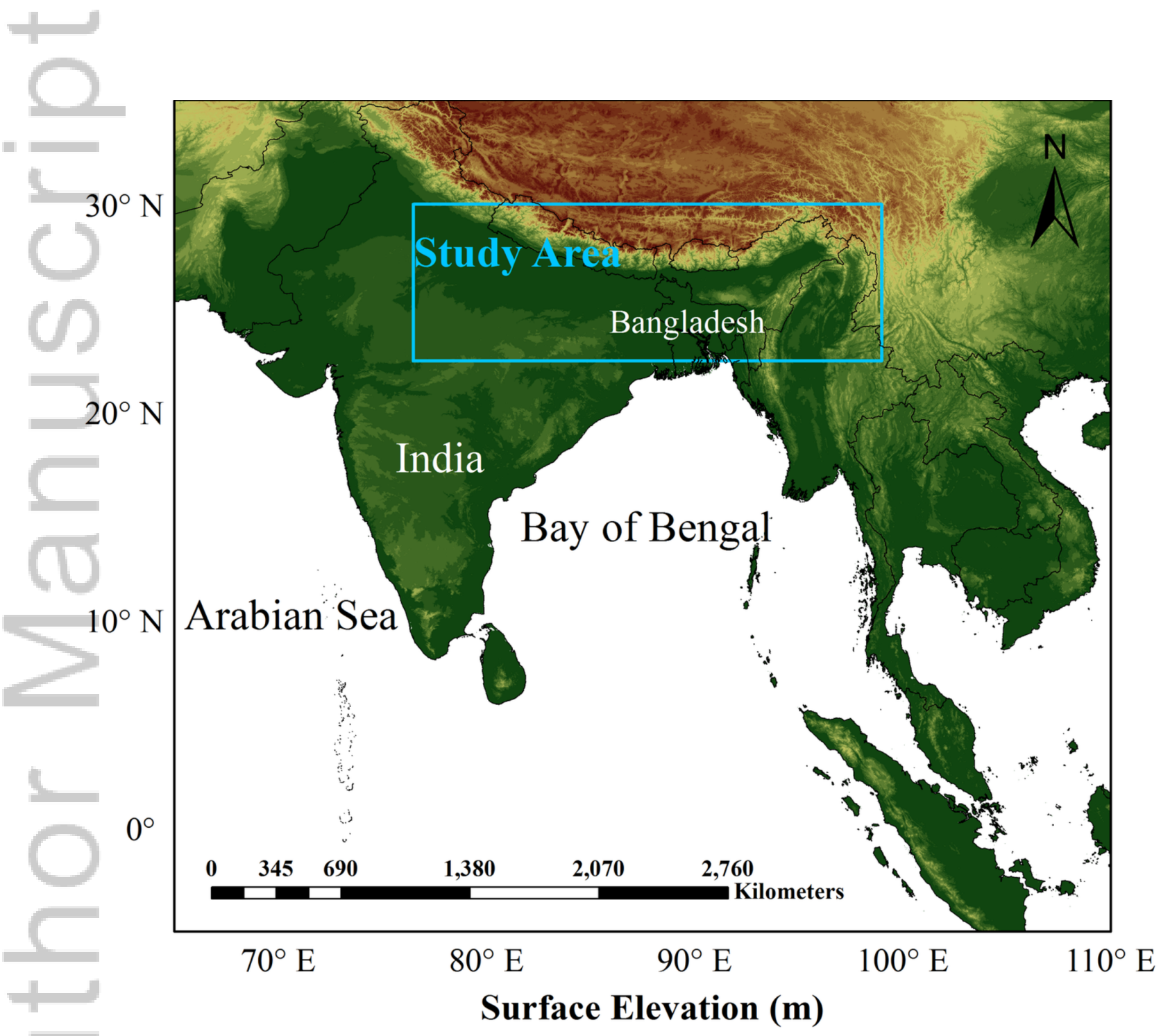

$\begin{array}{llllllllllllll}-158 & 270 & 633 & 1,028 & 1,424 & 1,885 & 2,412 & 3,006 & 3,599 & 4,126 & 4,555 & 4,885 & 5,181 & 5,577\end{array}$

Figure1.tif

This article is protected by copyright. All rights reserved. 


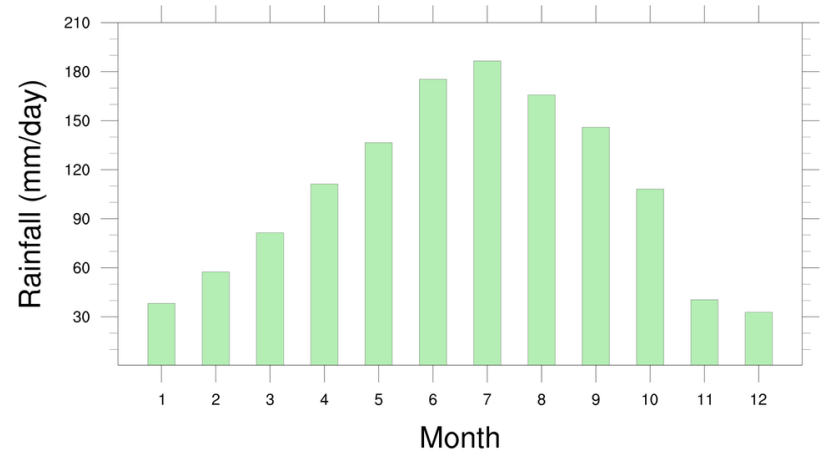

Figure2.tif

This article is protected by copyright. All rights reserved. 


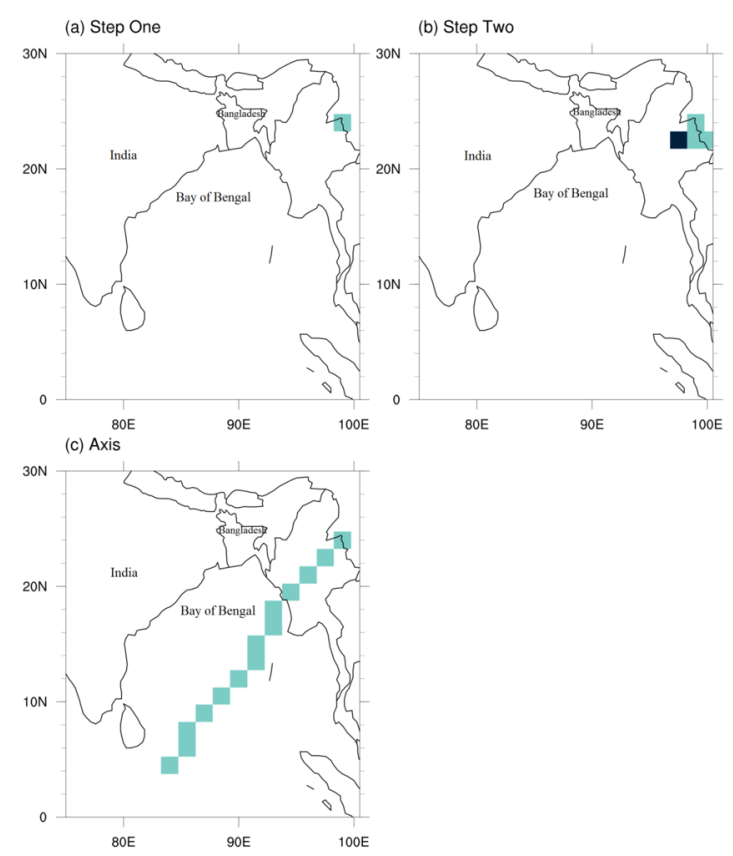

Figure3.tif

This article is protected by copyright. All rights reserved. 


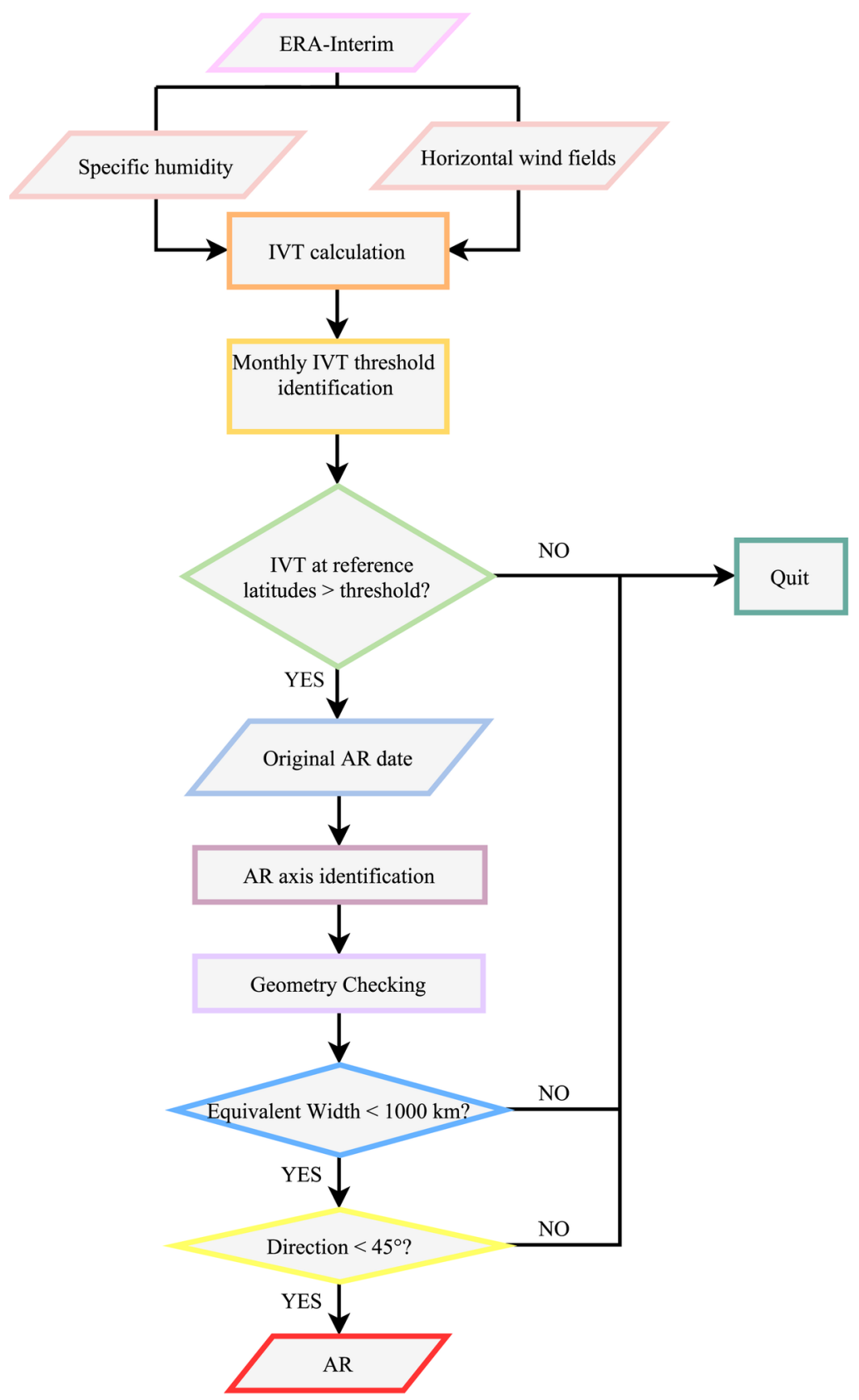

Figure4.tif

This article is protected by copyright. All rights reserved. 


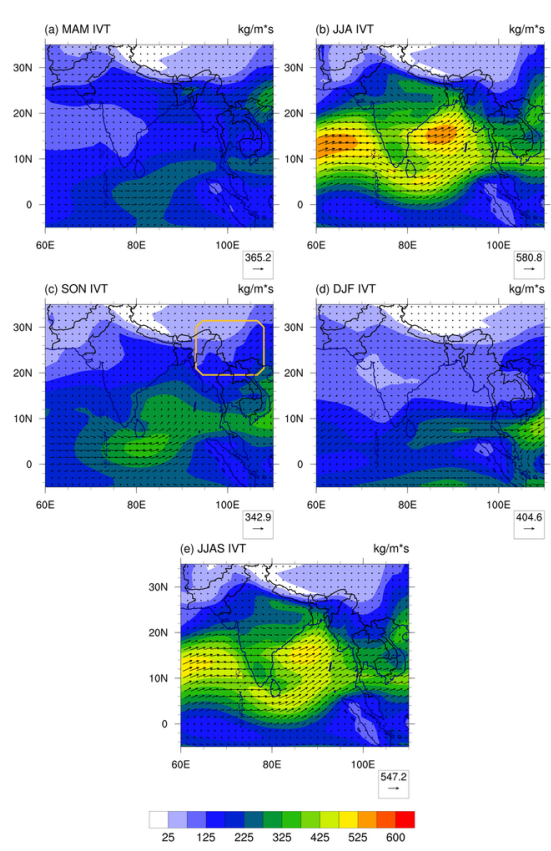

Figure5.tif

This article is protected by copyright. All rights reserved. 


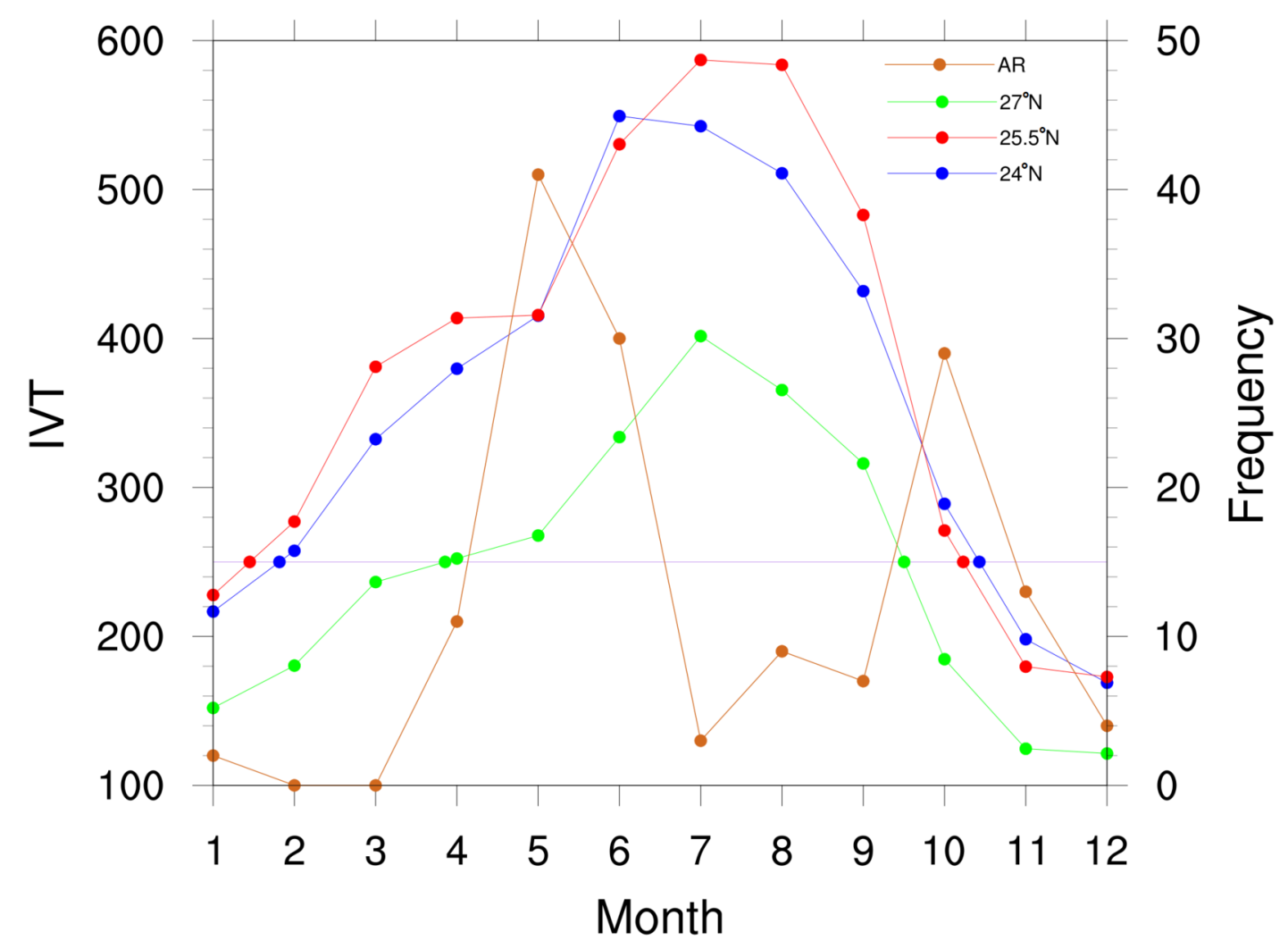

Figure6.tif

This article is protected by copyright. All rights reserved. 


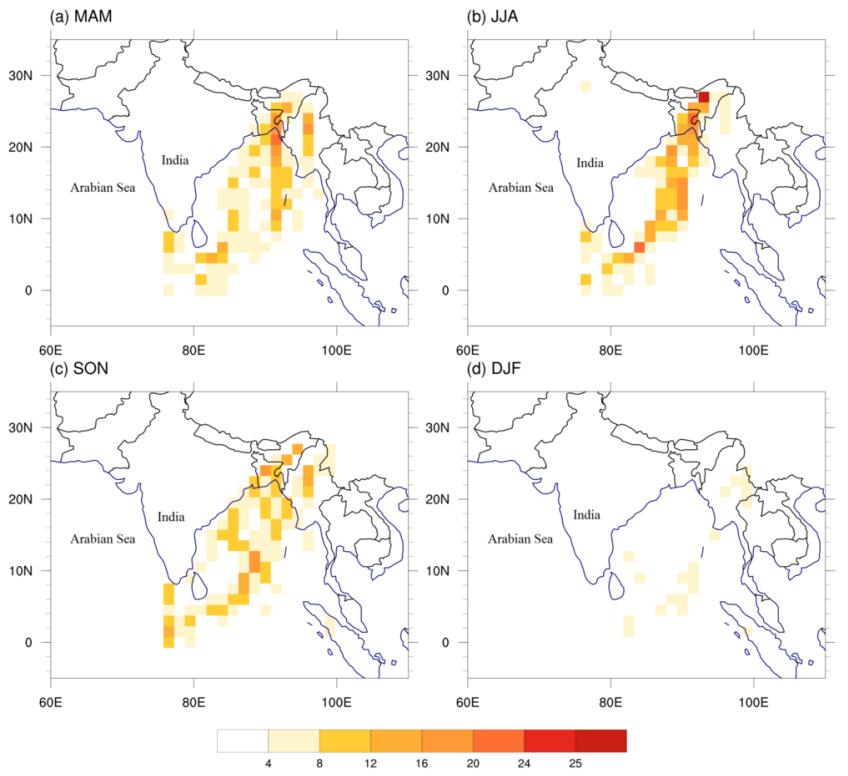

Figure7.tif 


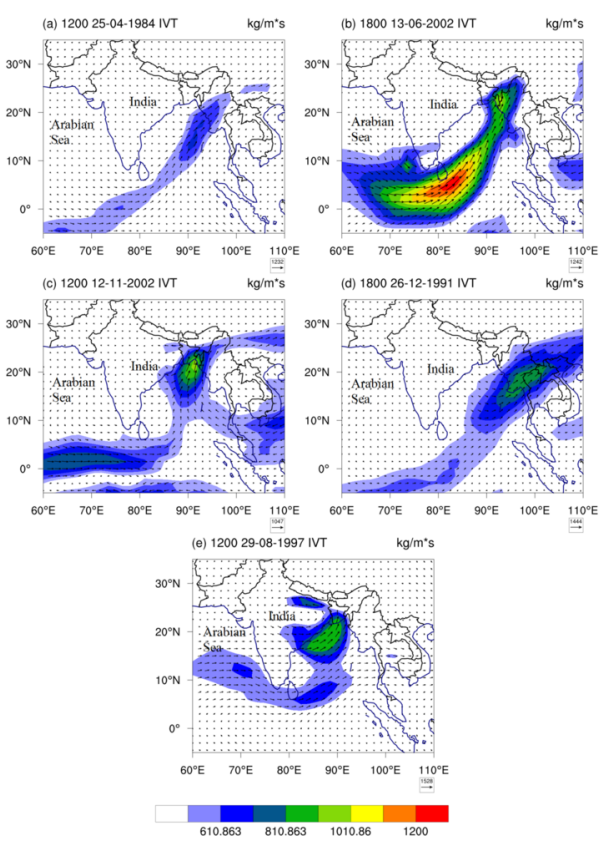

Figure8.tif

This article is protected by copyright. All rights reserved. 


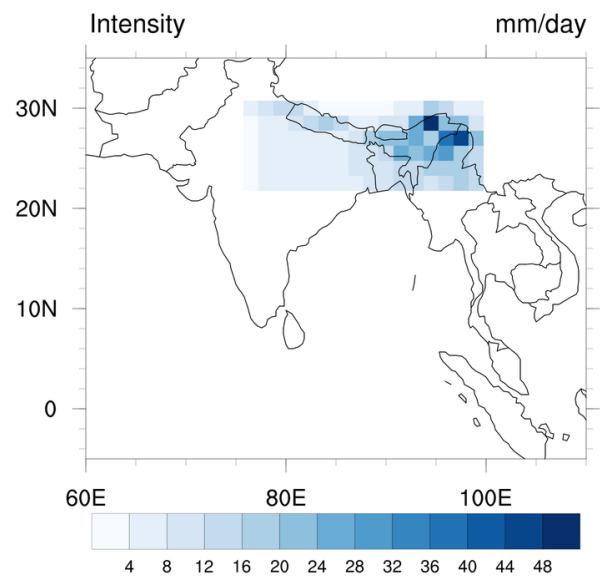

Figure9.tif

This article is protected by copyright. All rights reserved. 
(a) $r_{\mathrm{ER}}$

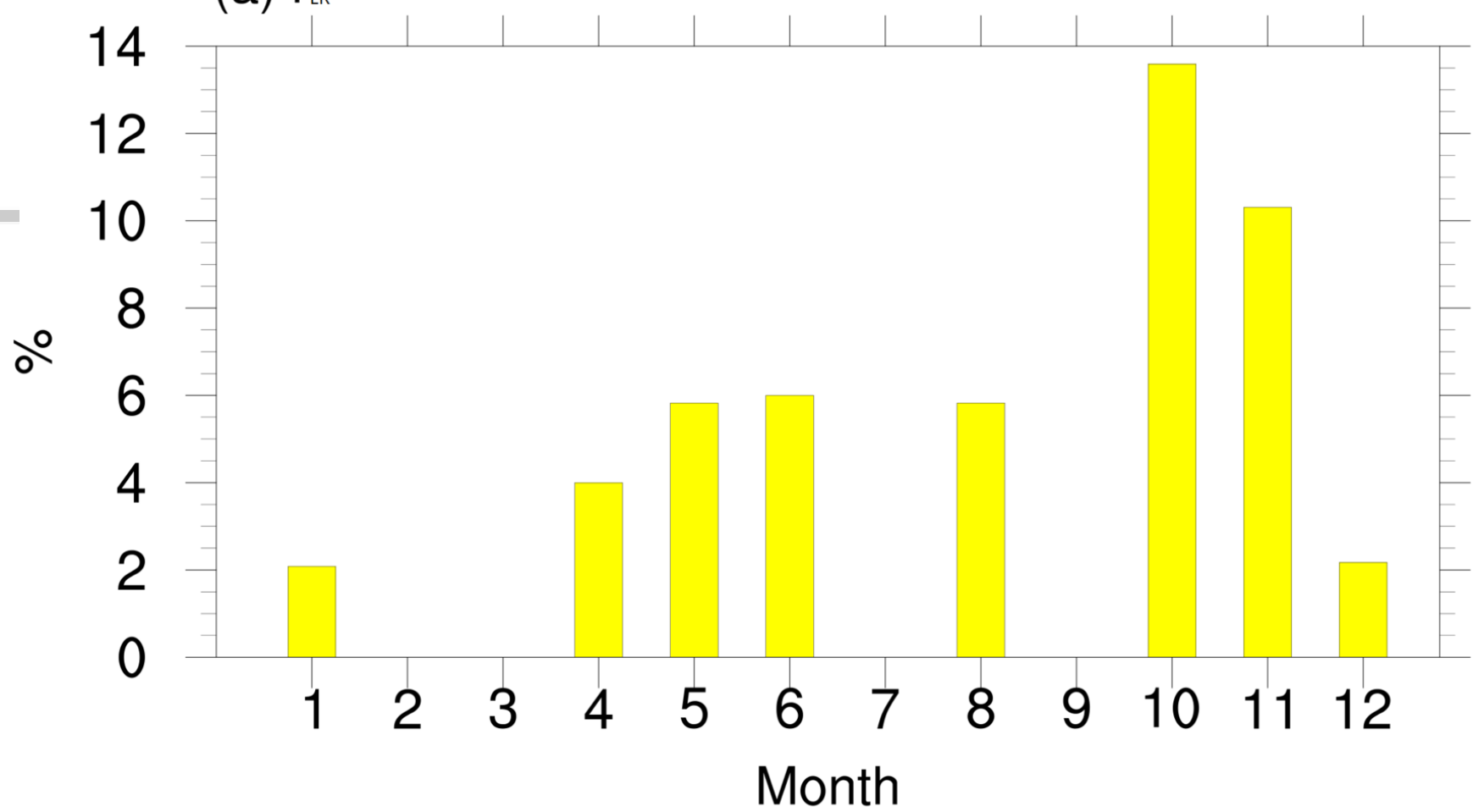

(b) $r_{A R}$

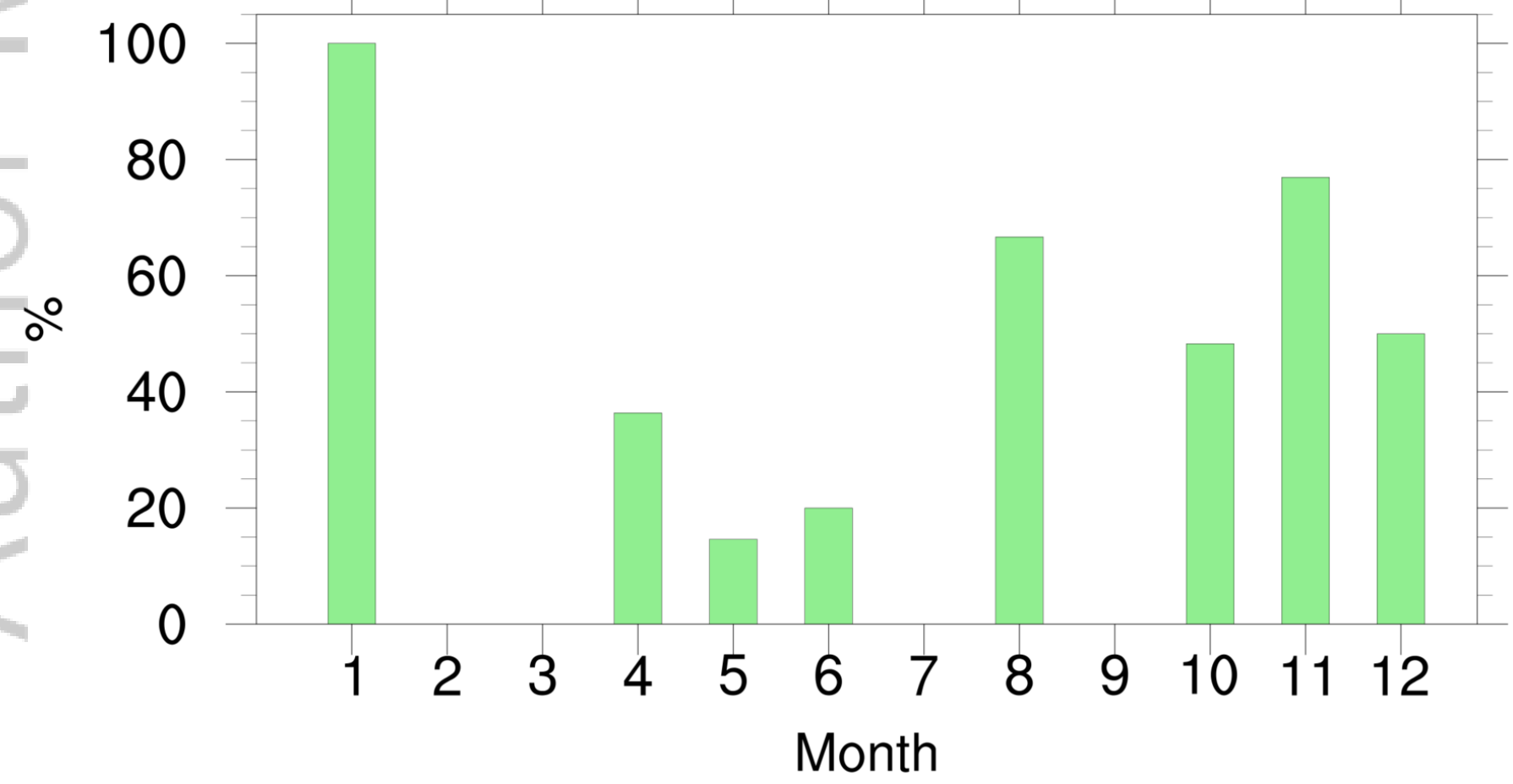

Figure10.tif 


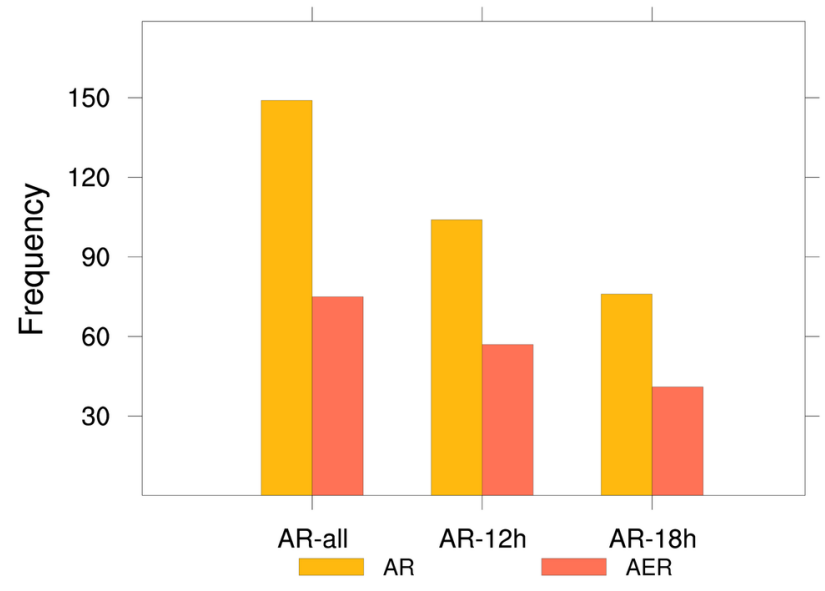

Figure11.tif

This article is protected by copyright. All rights reserved. 


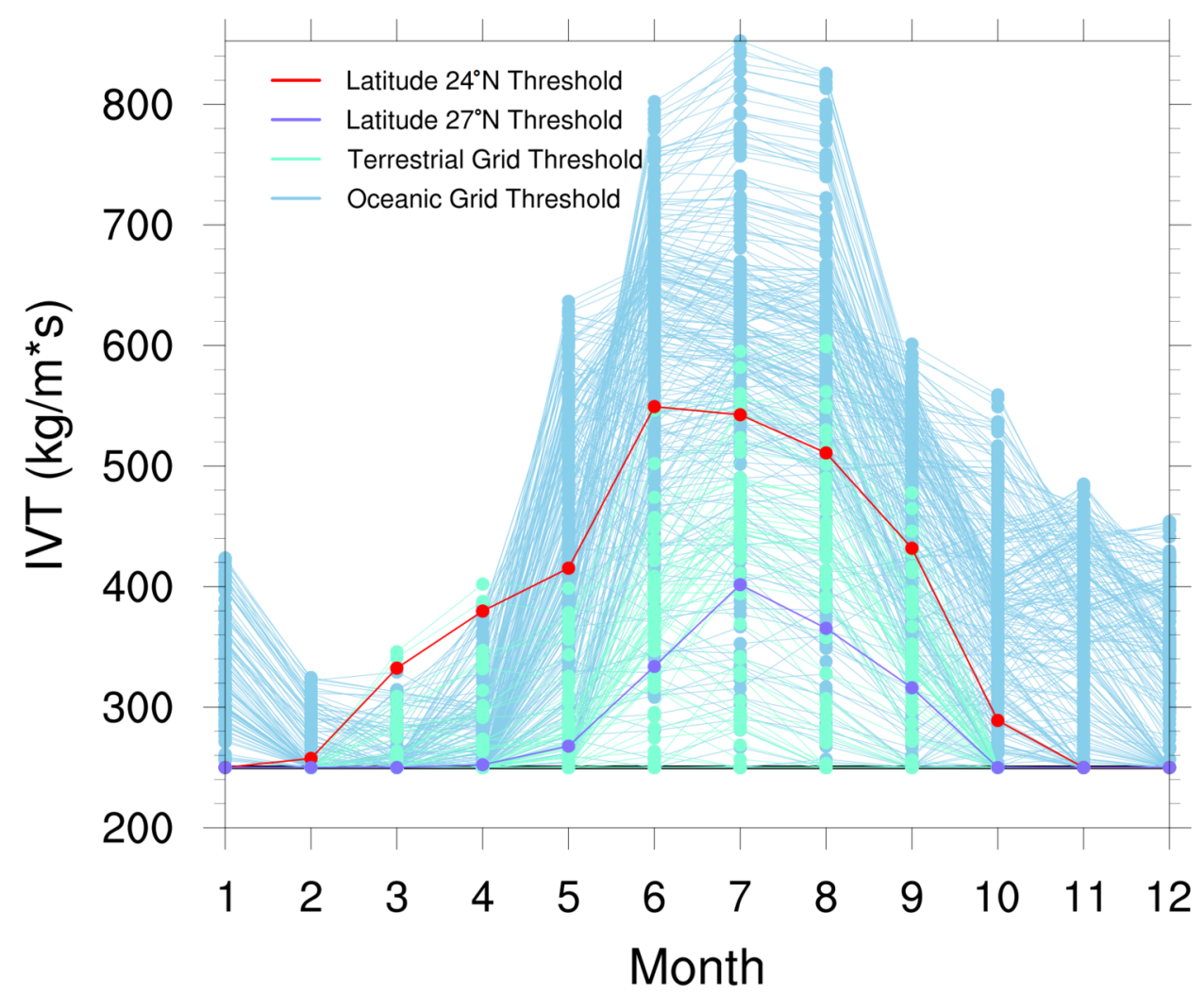

Figure_A1.tif

This article is protected by copyright. All rights reserved. 

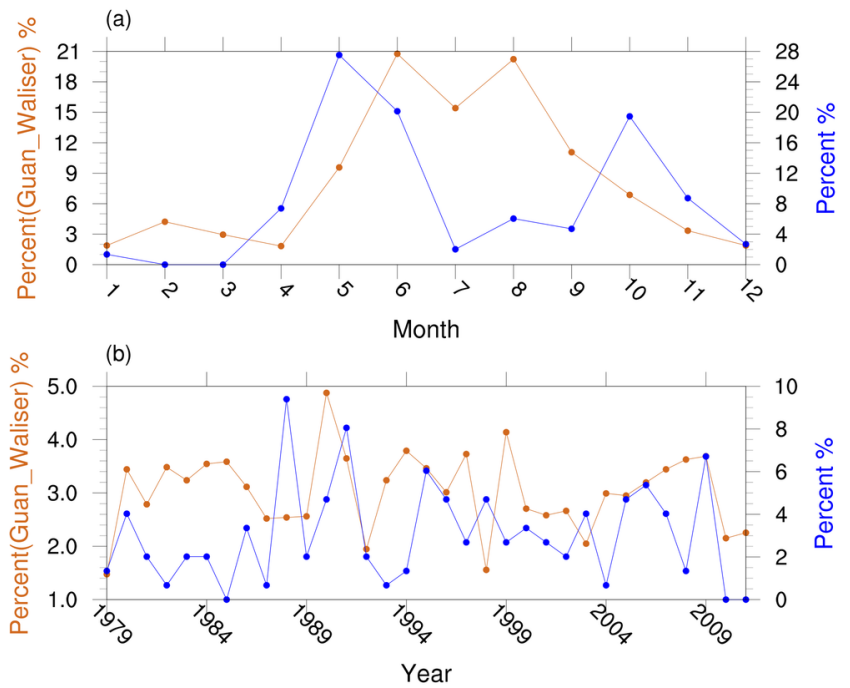

Figure_A2.tif

This article is protected by copyright. All rights reserved. 


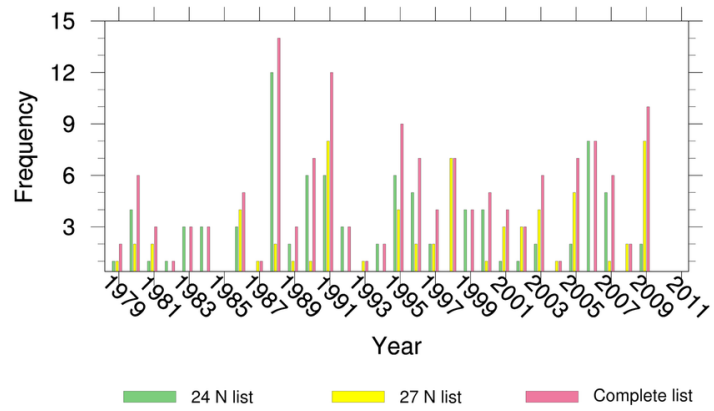

Figure_A3.tif

This article is protected by copyright. All rights reserved. 


\section{Figure Captions:}

Figure 1 Observed (30 arc s) topography (shaded in $\mathrm{m}$ ) for the Bay of Bengal (BOB) and part of Asia. The location of study area is shown in blue box (from $\left(76.5^{\circ} \mathrm{E}, 22.5^{\circ} \mathrm{N}\right.$ ) to $\left.\left(99^{\circ} \mathrm{E}, 30^{\circ} \mathrm{N}\right)\right)$. The west-east boundary is based on the extent of BOB and the south-north boundary represents the northern continental area between coast and the Himalayas. The country boundaries are presented by black lines.

Figure 2 Monthly extreme rainfall thresholds defined as the $90^{\text {th }}$ percentile of the maximum daily rainfall (larger than $1 \mathrm{~mm}$ ) over the study region during 1979-2011.

Figure 3 The AR axis structure identification algorithm. (a) The blue grid indicates the location of maximum IVT between $76.5^{\circ} \mathrm{E}$ and $99^{\circ} \mathrm{E}$ at $24^{\circ} \mathrm{N}$ (reference latitude), which serves as the ending point of the axis. (b) The next step is to search the adjacent grid cells (to the south/ southeast/ southwest) for highest IVT. The black grid represents the selected highest IVT location. (c) Repeat step two for 13 times and obtain the axis structure (the connected blue line).

Figure 4 The flowchart for AR identification algorithm.

Figure 5 The seasonal mean IVT (in $\mathrm{kg} / \mathrm{m}^{-1} \mathrm{~s}^{-1}$ ) in (a) spring, (b) summer, (c) autumn, (d) winter and (e) monsoon season. The yellow box (from $\left(21^{\circ} \mathrm{N}, 95^{\circ} \mathrm{E}\right)$ to $\left(30^{\circ} \mathrm{N}, 106^{\circ} \mathrm{E}\right)$ ) represents the spatial scope of Longitudinal Range-Gorge Region (Wu et al. 2012).

Figure 6 The monthly IVT strength thresholds at $24^{\circ} \mathrm{N}$ (blue), $25.5^{\circ} \mathrm{N}$ (red) and $27^{\circ} \mathrm{N}$ (green) in the study area (left axis). The IVT strength threshold is determined as follows. The maximum values of IVT at certain latitudes at 1200 UTC of each day are first regrouped by month, then the $85^{\text {th }}$ percentiles of each group are determined as the monthly thresholds. The purple line of $250 \mathrm{~kg} \mathrm{~m}^{-1} \mathrm{~s}^{-1}$ represents the lower limit of IVT strength (left axis). The chocolate line displays the intra-annual distribution of ARs identified over the Bay of Bengal during 1979-2011(right axis).

Figure 7 The spatial occurrence of ARs that is shown as the seasonal-accumulative occurrence frequency of AR axis in each grid.

Figure 8 Examples of five ARs shown in IVT (in kg m $\mathrm{s}^{-1}$ ) at (a) 1200UTC $25^{\text {th }}$ April 1984 , (b) 1800 UTC $13^{\text {th }}$ June 2002, (c) 1200UTC $12^{\text {th }}$ November 2002, (d) 1800UTC $26^{\text {th }}$ December 1991, and (e) 1200 UTC $29^{\text {th }}$ August 1997. Note that the lower limit is the IVT threshold of the corresponding month.

Figure 9 the spatial distribution of mean ER intensity over study area.

Figure 10 (a) and (b) are $r_{\mathrm{ER}}$ (the occurrences of AREs over all ERs) and $r_{\mathrm{AR}}$ (the 
occurrences of AERs over all ARs) respectively.

Figure 11 Frequency of AERs in three groups.

Figure A1 Monthly variations of IVT strength threshold of different areas: oceanic grids (blue, from $\left(76.5^{\circ} \mathrm{E}, 0^{\circ} \mathrm{N}\right)$ to $\left(99^{\circ} \mathrm{E}, 22.5^{\circ} \mathrm{N}\right)$ ), terrestrial grids (green, from $\left(76.5^{\circ} \mathrm{E}, 24^{\circ} \mathrm{N}\right)$ to $\left.\left(99^{\circ} \mathrm{E}, 30^{\circ} \mathrm{N}\right)\right)$, reference latitude $24^{\circ} \mathrm{N}$ (red), and reference latitude $27^{\circ} \mathrm{N}$ (purple). The black line indicates the lower limit of IVT threshold of $250 \mathrm{~kg} \mathrm{~m}^{-1}$ $\mathrm{s}^{-1}$.

Figure A2 The (a) intra-annual and (b) inter-annual AR distribution of Guan and Waliser (2015) global AR dataset (brown) and our results (blue).

Figure A3 Time series of identified ARs over 1979-2011. The green bars and yellow bars show the $24^{\circ} \mathrm{N}$ and $27^{\circ} \mathrm{N}$ list respectively, and the pink bars represents the complete list. 


\section{University Library}

\section{- M M N E R VA A gateway to Melbourne's research publications}

Minerva Access is the Institutional Repository of The University of Melbourne

Author/s:

Yang, Y;Zhao, T;Ni, G;Sun, T

Title:

Atmospheric rivers over the Bay of Bengal lead to northern Indian extreme rainfall

Date:

2018-02-01

Citation:

Yang, Y., Zhao, T., Ni, G. \& Sun, T. (2018). Atmospheric rivers over the Bay of Bengal lead to northern Indian extreme rainfall. INTERNATIONAL JOURNAL OF CLIMATOLOGY, 38 (2), pp.1010-1021. https://doi.org/10.1002/joc.5229.

Persistent Link:

http://hdl.handle.net/11343/293295 